\title{
The Action of Vibrio cholerae and Corynebacterium diphtheriae Neuraminidases on the Sendai Virus Receptor of Human Erythrocytes
}

\author{
By KAREN J. FIDGEN \\ Department of Biological Chemistry, Wellcome Research Laboratories, \\ Beckenham BR3 3BS, Kent
}

(Received I5 November 1974; revised 7 February 1975)

\section{SUMMARY}

Studies of the Sendai virus haemagglutinin receptor on the human erythrocyte surface have confirmed that it involves $2 \rightarrow 3$ linked sialic acid. Because the primary specificity of Vibrio cholerae neuraminidase is for this linkage, it is able to compete with the virus for the receptor, to which it adsorbs strongly at low temperatures. Corynebacterium diphtheriae neuraminidase, whose principal specificity is for a sialic acid linkage other than $2 \rightarrow 3$, does not easily remove Sendai virus receptors, nor does it adsorb to the erythrocyte surface. A new definition of the term 'receptordestroying enzyme' is given which takes both enzyme and virus specificity into account, and a modified assay method is suggested in order to overcome the problems due to enzyme adsorption.

\section{INTRODUCTION}

The observation that myxoviruses are able to agglutinate erythrocytes (Hirst, 194I; McClelland \& Hare, 194I) led to the discovery of a viral enzyme which was able to remove from the red cell surface the receptor involved in the haemagglutination reaction. An enzyme with similar properties was also found in the culture filtrates of certain bacteria (e.g. Vibrio cholerae) and, because of its receptor-destroying activity, it was named 'receptor-destroying enzyme' (RDE) (Burnet \& Stone, 1947). Later experiments showed that RDE removed sialic acid (neuraminic acid) from glycoproteins and consequently it was renamed neuraminidase (Gottschalk, 1957; Heimer \& Meyer, 1956), with the result that the terms RDE and neuraminidase have, in general, been considered synonymous ever since.

While studying the properties of Corynebacterium diphtheriae neuraminidase, it was found that the enzyme failed to destroy myxovirus receptors on erythrocytes. The modes of action of this enzyme and of $V$. cholerae neuraminidase on myxovirus receptors were therefore investigated as reported here.

\section{METHODS}

Neuraminidases. Vibrio cholerae RDE, containing 50 units $/ \mathrm{ml}$, was prepared by Wellcome Reagents Ltd, Wellcome Research Laboratories, Beckenham, Kent. A highly purified $V$. cholerae neuraminidase (VCN) preparation, containing 500 units $/ \mathrm{ml}$, was obtained from BDH. A preparation of $C$. diphtheriae neuraminidase (CDN), containing 5000 units/ml, was prepared in this laboratory by ammonium sulphate fractionation and gel filtration on Biogel PI50 (Bio-Rad Laboratories). Neuraminidase activity is expressed as $\mu \mathrm{g} N$-acetyl neuraminic acid (NANA) released in I5 min at $37^{\circ} \mathrm{C}$ from $\alpha_{1}$-acid glycoprotein substrate. 
The abbreviations VCN and RDE both refer to $V$. cholerae neuraminidase. They are each employed in the text to denote which batch of enzyme was used in the experiment being described.

Erythrocytes. Freshly drawn group $\mathrm{O}$ human erythrocytes from a healthy individual were suspended in calcium chloride saline (CCS), consisting of $0.85 \% \mathrm{NaCl}$ containing $0.1 \%$ $\mathrm{CaCl}_{2}$.

Substrates. Human $\alpha_{1}$-acid glycoprotein, prepared from the supernatant of Cohn fraction V by the Scottish National Blood Transfusion Service, Edinburgh (Fraser \& Smith, 1975), was made up in solutions containing $5 \mathrm{mg} / \mathrm{ml} \mathrm{CCS}$. Sialyl lactose was prepared from bovine colostrum (Schneir \& Rafelson, 1966). Colominic acid was a gift from Dr P. J. Somers, Department of Chemistry, The University, Birmingham I 5 . For the enzyme specificity studies, solutions of the substrates were made up in $0.02 \mathrm{M}$-sodium phosphate buffer, $\mathrm{pH} 6 \cdot 0$.

Virus suspension. A suspension of Sendai virus, kindly donated by $\mathrm{Dr} \mathrm{K}$. Apostolov, Hammersmith Hospital, London, W.I2, was freeze-dried and inactivated by heating the lyophilized material at $100^{\circ} \mathrm{C}$ for $30 \mathrm{~min}$ (Apostolov \& Damjanovic, 1973). This procedure only destroyed its infectivity; haemolysin, haemagglutinin and neuraminidase activities remained intact. The inactivated virus was suspended in CCS.

Assay of virus haemagglutinating activity. Serial doubling dilutions of $50 \mu \mathrm{l}$ virus suspension in CCS (from undiluted to I/5I2) were mixed with $0.1 \mathrm{ml}$ of a $0.5 \%$ (v/v) erythrocyte suspension in a microtitre plate. The volume in each well was made up to $0.2 \mathrm{ml}$ with $50 \mu \mathrm{l}$ of CCS and the cells left to sediment. Agglutination was indicated by a diffuse layer of erythrocytes at the bottom of a well; the virus titre, expressed as the ' $50 \%$ end point', was taken as the highest dilution of virus giving a pattern showing a ring of partially sedimented cells on a background of agglutinated cells; in a negative reaction the red cells settled to form a compact button.

Assay of NANA. The quantity of NANA released into the incubation medium by RDE treatment of erythrocytes was assayed automatically with a Technicon Autoanalyser (Fidgen, 1973).

Assay of receptor-destroying activity. Fifty $\mu \mathrm{l}$ of serial doubling dilutions of test material in CCS (from undiluted to $\mathrm{I} / 5 \mathrm{I} 2$ ) were incubated in a microtitre plate with $0 . \mathrm{I} \mathrm{ml} \mathrm{of} 0.5 \%$ $(\mathrm{v} / \mathrm{v})$ human $\mathrm{O}$ group erythrocytes for $\mathrm{I} 20 \mathrm{~min}$ at $37^{\circ} \mathrm{C}$. Eight haemagglutination (ha.) units of Sendai virus in $50 \mu \mathrm{l}$ were added to each well with mixing and the erythrocytes allowed to sediment. The microtitre mixtures were left at 4 or $20^{\circ} \mathrm{C}$, according to the conditions of the experiment and the ' $50 \%$ end point' was normally read (without shaking the plates) $24 \mathrm{~h}$ after the addition of virus.

A haemagglutination control containing erythrocytes and virus, and a sedimentation control containing erythrocytes and CCS, were also set up.

Assay of enzyme adsorbed to erythrocytes. One $\mathrm{ml}$ of a $10 \%$ (v/v) suspension of erythrocytes in CCS was incubated for $2 \mathrm{~h}$ at $37^{\circ} \mathrm{C}$ with I $\mathrm{ml}$ doubling dilutions of test material. The cells were sedimented at $600 \mathrm{~g}(5 \mathrm{~min})$, washed twice with $2 \mathrm{ml}$ ice-cold CCS and the volume adjusted to $\mathrm{I} \cdot 0 \mathrm{ml} . \alpha_{1}$-Acid glycoprotein $(\mathrm{I} \mathrm{ml}$ ) was added to $0.5 \mathrm{ml}$ of the washed suspension and $\mathrm{r} \cdot 0 \mathrm{ml}$ of CCS added to the remaining $0.5 \mathrm{ml}$. The two sets of tubes were incubated for $18 \mathrm{~h}$ at $37^{\circ} \mathrm{C}$ and the adsorbed enzyme activity estimated by assaying separately the NANA released from exogenous glycoprotein substrate and from the erythrocyte surface. The NANA released from the glycoprotein reflected the amount of enzyme adsorbed to the cell. That released from the erythrocyte surface alone indicated whether the adsorbed enzyme was capable of cleaving the available NANA residues.

Estimation of total erythrocyte NANA. One $\mathrm{ml}$ of a $10 \%$ suspension of erythrocytes in 


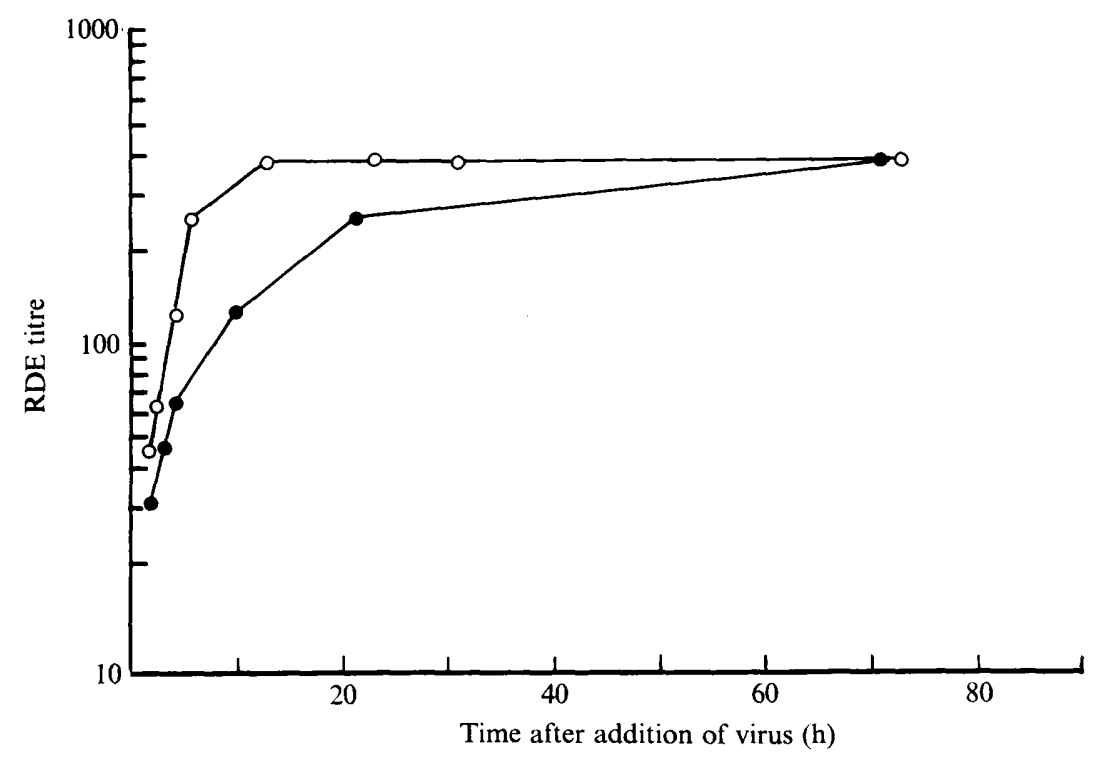

Fig. I. The increase in RDE titre with time after the addition of virus. RDE was incubated with $0.5 \%$ erythrocytes at $37^{\circ} \mathrm{C}$ for $2 \mathrm{~h}$. After the addition of virus, the plates were left at $(\mathrm{O}) 20^{\circ} \mathrm{C}$ or (O) $4{ }^{\circ} \mathrm{C}$.

CCS was centrifuged and the cells were lysed with distilled water. The cell stroma was washed until no more coloration due to haemoglobin could be seen. The volume of the cell suspension was adjusted to $0.5 \mathrm{ml}$ and $0.5 \mathrm{ml} 0.05 \mathrm{M}-\mathrm{H}_{2} \mathrm{SO}_{4}$ added. The mixture was heated at $80^{\circ} \mathrm{C}$ for $\mathrm{I} h$ and the supernatant was assayed for NANA. Each estimation was performed in duplicate, and NANA standards in a range from 5 to $50 \mu \mathrm{g} / \mathrm{ml}$ were treated in parallel.

\section{RESULTS}

Progress of receptor destruction after the addition of virus

Two identical RDE assays were set up as described in Methods. After incubation at $37^{\circ} \mathrm{C}$ one microtitre plate was left at $4{ }^{\circ} \mathrm{C}$ and the other at $20^{\circ} \mathrm{C}$.

In the plate left at $4{ }^{\circ} \mathrm{C}$, the destruction of receptors, as demonstrated by the progressive change from an agglutinated to a sedimented pattern of erythrocytes at higher dilutions of enzyme, continued for several days until an apparently steady titre, the 'final' titre, was reached. When the microtitre mixtures were left at $20^{\circ} \mathrm{C}$ this titre was reached more quickly (Fig. I). The progressive sedimentation was not due to the action of the viral neuraminidase causing elution of the virus from the erythrocyte surface, since the controls which contained only virus and erythrocytes did not sediment but remained haemagglutinated throughout the test. Therefore the destruction of myxovirus receptors by RDE was apparently able to continue in the presence of excess virus and at low temperatures.

\section{Effect of incubation time on RDE titre}

To test the effect of incubation time on RDE titre, four parallel RDE assays were set up as previously described and were incubated for $0,1,2$ and $4 \mathrm{~h}$ respectively before the virus was added. The length of time for which the enzyme and erythrocytes were incubated at 


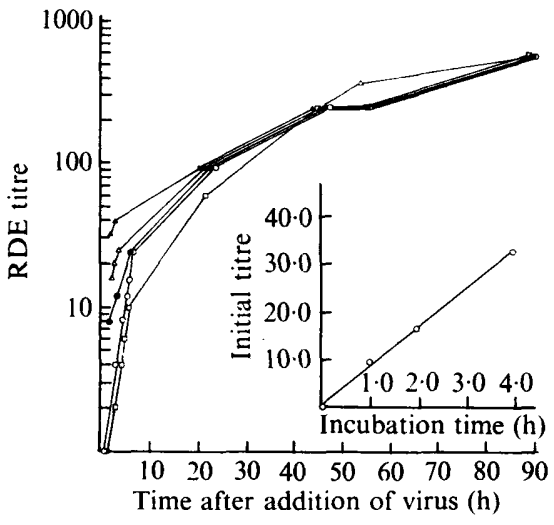

Fig. 2

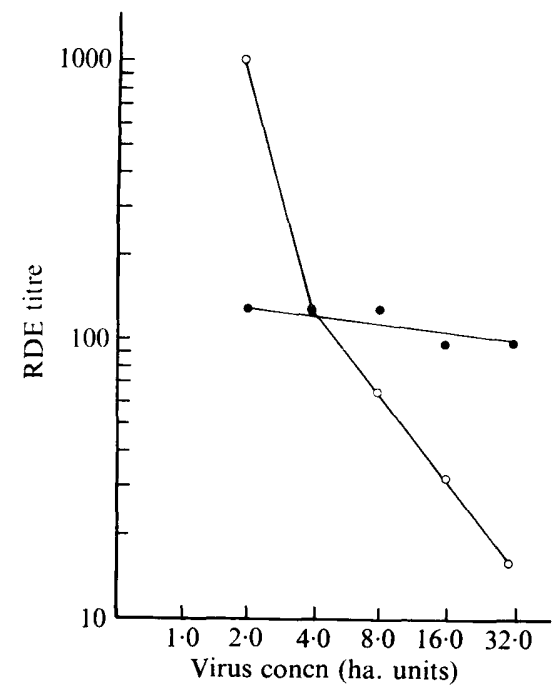

Fig. 3

Fig. 2. Lack of effect of length of incubation time on final RDE titre. Dilutions of RDE were incubated with $0.5 \%$ erythrocytes for $(O) \circ \mathrm{h},(O) \mathrm{I} \mathrm{h},(\Delta) 2 \mathrm{~h}$, or $(\Delta) 4 \mathrm{~h}$ before the addition of $8 \mathrm{ha}$. Sendai virus. For comparison, dilutions of enzyme were added to haemagglutinated erythrocytes $(\square)$. The inset represents the plot of the initial titres (read immediately after the erythrocytes controls had sedimented) against incubation time.

Fig. 3. The effect of virus concentration on the RDE final titre. Dilutions of RDE and $0.5 \%$ erythrocytes were mixed without incubation and $50 \mu 1$ Sendai virus containing $2 \rightarrow 32$ ha. were added. The plates were left at $(\bigcirc) 20^{\circ} \mathrm{C}$ or $(\bigcirc) 4{ }^{\circ} \mathrm{C}$ and the results were read after $24 \mathrm{~h}$.

$37^{\circ} \mathrm{C}$ did not affect the final RDE titre (Fig. 2). However, when the results were read immediately after the erythrocyte controls had sedimented (approximately $\mathbf{I} \mathbf{h}$ after the addition of virus) the initial titre was proportional to incubation time (Fig. 2 inset). For comparison, dilutions of enzyme were added to erythrocytes which had already been haemagglutinated by virus. Progressive sedimentation of the erythrocytes occurred as before and the RDE titre was independent of the order in which the reagents were added.

These results indicated that the RDE reaction was complex. If the final titre were determined only by neuraminidase action before the addition of virus, it would be affected by the enzyme-erythrocyte incubation time. If the virus were solely a reagent which terminated the reaction by haemagglutinating the cells, the already agglutinated erythrocytes would not still be susceptible to neuraminidase action. These considerations indicate that RDE reaction involves both the enzymic removal of myxovirus receptors and also some other interaction in which the enzyme and the virus are in competition.

\section{Effect of virus concentration on $R D E$ titre}

Erythrocytes were mixed with dilutions of RDE and exposed to haemagglutination by a series of Sendai virus suspensions containing from 2 to 32 ha. units in $50 \mu 1$. The RDE titre was inversely related to the concentration of virus at both $20^{\circ}$ and at $4{ }^{\circ} \mathrm{C}$, although the relationship was more marked at the higher temperature (Fig. 3). Since, in this experiment, the enzyme and erythrocytes were not incubated together before the addition of virus, these results are interpreted as reflecting competition between enzyme and virus for a NANA receptor on the erythrocyte surface. 

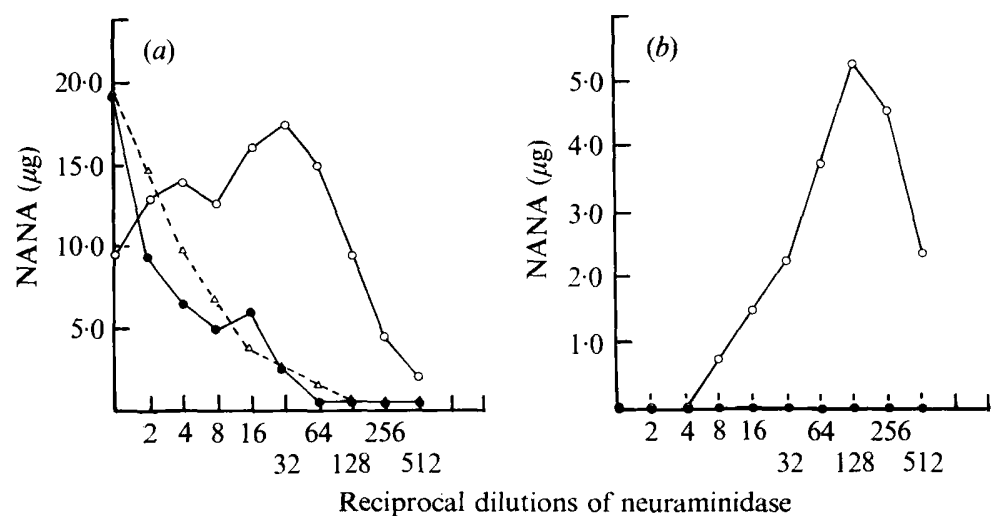

Fig. 4. The adsorption of RDE and CDN to erythrocytes. (a) Neuraminidase activity shown by enzyme adsorbed to erythrocytes when incubated with $\alpha_{1}$-acid glycoprotein. (b) Sialic acid released from erythrocyte surface by adsorbed enzyme during incubation in saline. $O, \operatorname{RDE}$ (50 units $/ \mathrm{ml}$ ); - $\mathrm{CDN}$ (5000 units/ml); $\triangle$, expected residual CDN activity, calculated from a dilution factor which took into account the number of washes and dilutions of the erythrocytes during the course of the experiment.

Neuraminidase action is very slow at $4{ }^{\circ} \mathrm{C}$, so a stable enzyme-erythrocyte complex is the predominant product of the reaction at this temperature (Ada, French \& Lind, I96I). At $20^{\circ} \mathrm{C}$ neuraminidase is able to bind to and then cleave the erythrocyte receptor. This makes the overall equilibrium in favour of the products of the neuraminidase reaction and not the intermediate enzyme-erythrocyte complex. Therefore at $4{ }^{\circ} \mathrm{C}$ the $\mathrm{RDE}$ titre would be expected to be virtually independent of virus concentration, since the formation of the stable enzyme-erythrocyte complex would prevent access of the virus to the erythrocyte receptor at all concentrations of virus. The shallow gradient of the $4{ }^{\circ} \mathrm{C}$ plot in Fig. 3 bears out this hypothesis. In contrast, at $20^{\circ} \mathrm{C}$ the enzyme-erythrocyte complex would not be the stable end product of the reaction since the neuraminidase reaction goes to completion at this temperature. In these circumstances the virus would be able to compete directly for the receptor, and the amount of haemagglutination which occurred should depend upon the relative concentrations of enzyme and virus. The $20^{\circ} \mathrm{C}$ plot in Fig. 3 shows that, as expected, the greatest amount of haemagglutination (i.e. the lowest RDE titre) occurred where the virus concentration was highest.

\section{Adsorption of neuraminidase to erythrocytes}

In view of these results and their implication that the myxovirus receptor might be masked by adsorbed enzyme, an experiment as described in Methods was carried out to determine whether neuraminidase from $V$. cholerae (RDE) and from $C$. diphtheriae (CDN) remained adsorbed to the surface of erythrocytes after incubation for $2 \mathrm{~h}$ at $37^{\circ} \mathrm{C}$. The CDN activity obtained after incubating the treated and washed erythrocytes for $18 \mathrm{~h}$ with glycoprotein substrate (Fig. 4a) was not significantly greater than that which could be attributed to residual CDN activity (calculated on the basis of the dilution of unadsorbed enzyme during the experiment), i.e. no CDN was adsorbed to the erythrocyte surface. There was insufficient CDN present to release further NANA from the cell surface during the $18 \mathrm{~h}$ incubation of erythrocytes in saline (Fig. $4 b$ ).

Although the RDE was Ioo times less potent than the CDN it was able to release a significantly greater quantity of NANA from the exogenous substrate and, in addition, all but 


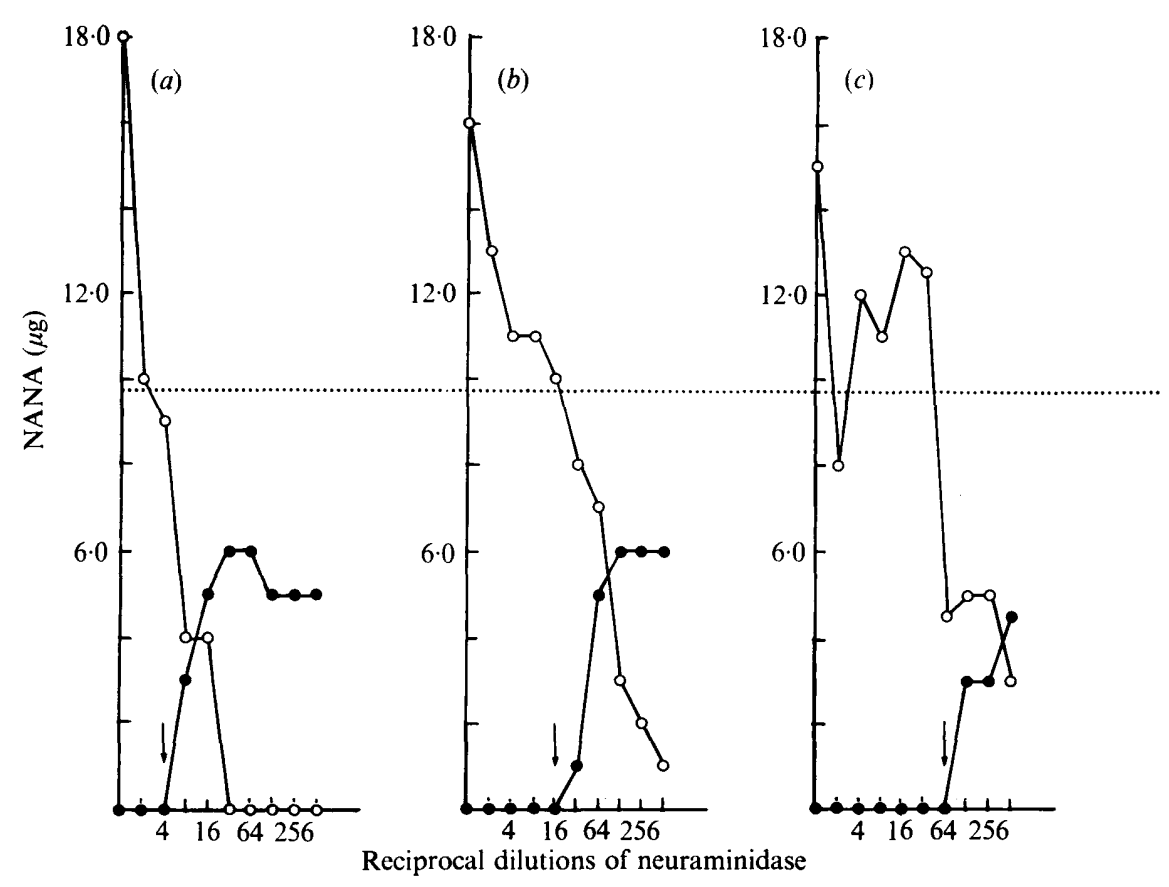

Fig. 5. The relationship between sialic acid linkage and adsorption of VCN to the erythrocyte surface. $O$, Sialic acid removed from erythrocytes during incubation with dilutions of VCN, at (a) $\circ \mathrm{h},(b)$ I h, (c) $2 \mathrm{~h}$. O, Sialic acid removed from erythrocytes by adsorbed enzyme during $18 \mathrm{~h}$ incubation. $\cdots, 2 \rightarrow 3$ linked NANA $\equiv 36 \%$ of total. The 'initial' titre is arrowed; the 'final' titre was $1 / 128$ in each instance.

the most concentrated samples of RDE were able to release NANA from the erythrocyte surface alone (Fig. $4 b$ ). These results indicate that neuraminidase was adsorbed to the erythrocyte surface at all dilutions of RDE after a $2 \mathrm{~h}$ incubation of enzyme and cells, but that the most concentrated samples of enzyme were unable to release additional sialic acid from the red cells during incubation in CCS. The ability to release additional NANA increased with enzyme dilution, which probably indicates that the more dilute samples of enzyme had been unable to cleave the available NANA residues during the initial $2 \mathrm{~h}$ incubation.

Drzeniek (1973) gives the substrate specificity of $V$. cholerae neuraminidase in order of linkage preference as $2 \rightarrow 3 \gg 2 \rightarrow 6>2 \rightarrow 8$, and the percentages of $2 \rightarrow 3$ and $2 \rightarrow 6$ linked sialic acid on the erythrocyte surface have been shown to be approximately 36 and $64 \%$, respectively (Constantopoulos, 1973). Therefore a possible explanation for the observations shown in Fig. 4 was that the adsorbed enzyme was bound to at least two types of NANA residues which differed only in their linkage to the cell surface; in the more concentrated samples the enzyme had cleaved the preferred NANA linkage and was bound to another linkage, which it could only cleave very slowly but from which it could elute to attack exogenous substrate. Accordingly an experiment was set up to investigate whether the ability of adsorbed RDE to release NANA from the cell surface depended upon the presence of a particular NANA linkage.

One $\mathrm{ml}$ doubling dilutions of VCN were incubated with $\mathrm{I} \cdot 0 \mathrm{ml}$ of $10 \%$ erythrocytes for 0 , I or $2 \mathrm{~h}$ at $37^{\circ} \mathrm{C}$. The cells were centrifuged and washed twice in ice-cold CCS and then 
Table I. Comparison of the action of Corynebacterium diphtheriae neuraminidase on substrates which have different sialic acid linkages

\begin{tabular}{|c|c|c|c|c|c|}
\hline \multirow[b]{3}{*}{ Substrate (and linkage) } & \multirow{3}{*}{$\begin{array}{c}\text { Sialic acid } \\
\text { content in } \\
\text { substrate } \\
(\mu \mathrm{g} \text { NANA })\end{array}$} & \multicolumn{4}{|c|}{ Sialic acid removed } \\
\hline & & \multicolumn{2}{|c|}{ In $7.5 \mathrm{~min}$} & \multicolumn{2}{|c|}{ In $15 \mathrm{~min}$} \\
\hline & & $\mu \mathrm{g}$ & $\begin{array}{l}\% \text { available } \\
\text { sialic acid }\end{array}$ & $\mu \mathrm{g}$ & $\begin{array}{l}\% \text { available } \\
\text { sialic acid }\end{array}$ \\
\hline \multirow{3}{*}{$\begin{array}{l}\text { Sialyl lactose } \\
(2-\rightarrow 3 \text { linked NANA) }\end{array}$} & 75 & $9 \cdot 0$ & $12 \cdot 0$ & $18 \cdot 0$ & $24 \cdot 0$ \\
\hline & 100 & $10 \cdot 0$ & $10 \cdot 0$ & $19 \cdot 0$ & $19 \cdot 0$ \\
\hline & 125 & $10 \cdot 0$ & $8 \cdot 0$ & $19 \cdot 0$ & $15 \cdot 2$ \\
\hline \multirow{3}{*}{$\begin{array}{l}\text { Colominic acid } \\
(2 \rightarrow 8 \text { linked NANA })\end{array}$} & 75 & - & - & $0 \cdot 75$ & $I \cdot O$ \\
\hline & 100 & -- & - & $2 \cdot 0$ & $2 \cdot 0$ \\
\hline & 125 & - & - & $2 \cdot 0$ & $\mathrm{I} \cdot 6$ \\
\hline$\alpha_{1}$-acid glycoprotein & 75 & $43 \cdot 0$ & $57 \cdot 3$ & $48 \cdot 0$ & $64 \cdot 0$ \\
\hline$(2 \rightarrow 3,2 \rightarrow 4,2 \rightarrow 6$ NANA & 100 & $59 \cdot 0$ & $59 \cdot 0$ & $62 \cdot 0$ & $62 \cdot 0$ \\
\hline linkages) & 125 & $66 \cdot 0$ & $52 \cdot 8$ & $73 \cdot 0$ & $58 \cdot 5$ \\
\hline
\end{tabular}

incubated in $1 \cdot 0 \mathrm{ml} \mathrm{CCS}$ for $18 \mathrm{~h}$ at $37^{\circ} \mathrm{C}$. The two incubation supernatants were assayed for free sialic acid. The total erythrocyte sialic acid was estimated by acid hydrolysis as described in Methods and was found to be $28 \mu \mathrm{g} / \mathrm{ml}$. Figure 5 shows that after $36 \%$ (approx. $9.7 \mu \mathrm{g}$ ) of the total erythrocyte sialic acid (i.e. all of the $2 \rightarrow 3$ linked NANA) had been removed during incubation with dilutions of $\mathrm{VCN}$, the enzyme, which remained bound to the washed cells, was unable to remove further cell surface sialic acid during an overnight incubation in CCS. Therefore since enzyme remains bound to the cells at all dilutions (Fig. 4), the VCN must have been bound to a sialic acid linkage which it could only cleave very slowly, that is, the $2 \rightarrow 6$ linkage. Furthermore, the initial RDE titre (i.e. read after approximately $I \mathrm{~h}$ ) corresponded to the dilution of enzyme at which all of the $2 \rightarrow 3$ linked NANA had been removed and it was not affected by virus concentration. Therefore the erythrocyte receptor for the Sendai virus haemagglutinin must be $2 \rightarrow 3$ linked NANA, and the competition between $\mathrm{VCN}$ and the virus must have been solely for this linkage. This result corroborates the evidence obtained by Zakstelskaya et al. (1972) who showed that the Sendai virus haemagglutinin binds to, and is inhibited by, a $2 \rightarrow 3$ linked NANA disaccharide, $\alpha$-NANA-2 $\rightarrow$ 3-D-glucose.

\section{Action of CDN on Sendai virus receptors}

When CDN was tested in the experimental system described under Progress of receptor destruction after the addition of virus, it showed no receptor-destroying activity and the erythrocytes remained haemagglutinated throughout the test. If, however, a prolonged incubation (about $\mathrm{I} 8 \mathrm{~h}$ ) with potent enzyme was carried out, then the CDN was able to destroy Sendai virus receptors.

The substrate specificity of CDN was studied using $\alpha_{1}$-acid glycoprotein $(2 \rightarrow 3,2 \rightarrow 4$ and $2 \rightarrow 6$ linked NANA), sialyl lactose $(2 \rightarrow 3$ linked NANA) and colominic acid $(2 \rightarrow 8$ linked NANA polymer). The proportion of sialic acid linkages in the glycoprotein has been shown to be 10 to $20 \% 2 \rightarrow 3$, and 80 to $90 \% 2 \rightarrow 6$ or $2 \rightarrow 4$ (Jeanloz, 1966). Substrate concentrations were adjusted to contain equal quantities of available sialic acid and a standard neuraminidase preparation was used in all the assays.

The results (Table I) indicate that the substrate specificity of CDN is for

$$
\left\{\begin{array}{l}
2 \rightarrow 4 \\
2 \rightarrow 6
\end{array} \gg 2 \rightarrow 3>2 \rightarrow 8\right. \text { linked NANA. }
$$


It is therefore possible that the destruction of $2 \rightarrow 3$ linked Sendai virus receptors by CDN only takes place after all of the $2 \rightarrow 6$ linked NANA residues on the erythrocyte surface have been preferentially cleaved by the enzyme.

\section{DISCUSSION}

These studies have shown that the term 'receptor-destroying enzyme' is misleading for two reasons: (i) It is not synonymous with neuraminidase, as CDN which is demonstrably a neuraminidase is only able to destroy Sendai virus receptors with difficulty. The neuraminidases which can accurately be called receptor-destroying enzymes are therefore those whose primary substrate specificity is for a linkage which is the same as the specificity of myxovirus haemagglutinin which is being used in the test. For example, $V$. cholerae and Clostridium perfringens neuraminidases could in this instance be called Sendai virus receptordestroying enzyme, since their common primary specificity is for $2 \rightarrow 3$ linked NANA (Drzeniek, 1973). Corynebacterium diphtheriae neuraminidase could only be referred to as an RDE in terms of a virus (as yet to be found) whose haemagglutinin was specific for a $2 \rightarrow 6$ linked NANA receptor.

(ii) Although VCN cleaves $2 \rightarrow 3$ linked NANA from the erythrocyte membrane, it is also able to displace virus from already haemagglutinated cells and to adsorb strongly to the receptor. It is this aspect of the RDE reaction which makes the present assay system unsatisfactory, since the continuing action of the adsorbed enzyme is responsible for the time-dependent increase in titre. The ultimate 'end point' is thus determined effectively by the adsorption equilibrium between enzyme and virus; it does not represent the dilution above which all the receptors have been removed, but an apparently steady state in which the overall equilibrium is in favour of haemagglutination and in which the enzyme reaction due to adsorbed enzyme occurs very slowly. In practice this is difficult to achieve except at low temperatures, since the erythrocytes tend to haemolyse while the titre is still increasing.

The conclusion to be drawn is that although the RDE assay for $\mathrm{VCN}$ ultimately gives a titre which depends on the potency of the VCN, it is unsatisfactory because it also depends on the time elapsed after the addition of virus. It is therefore necessary to read the plates at an arbitrarily fixed time after the virus has been added and, because of this, a reference preparation of neuraminidase with the same characteristics as the enzyme to be tested must be included. Since the reaction depends both on the specificity of the enzyme and on its ability to adsorb to the sialic acid receptor, the nature of the reaction of neuraminidases from different sources must be known before a suitable reference preparation can be chosen. In view of these complications one can only conclude that it is much more reliable and also simpler to assay neuraminidase activity by measuring the release of NANA from suitable substrates by the thiobarbituric acid reaction (Warren, 1959; Aminoff, 196I).

The ability of VCN to adsorb strongly to the erythrocyte surface is important for another reason. Recently, the literature on the action of neuraminidase on various cell systems has greatly increased and in the majority of papers VCN has been the enzyme used. In view of our results and those of McQuiddy \& Lilien (1973) who found that VCN adsorbed strongly to neural retina cells, it seems necessary to emphasize that in certain circumstances the enzyme may adsorb to cells and interfere with subsequent reactions.

Whether this ability to adsorb strongly to cells is a characteristic of neuraminidases from other sources is not known so far. Collee (1965) has reported the existence of a temperatureindependent myxovirus receptor-inactivating agent from Clostridium welchii which gave similar results to those reported here. However, since the neuraminidases are diverse in 
their specificity both for sialic acid linkage and substitution (Drzeniek, 1973), it seems likely that this phenomenon is more widespread than hitherto realized.

I thank Mr J. M. Norris for his excellent technical assistance.

\section{REFERENCES}

AdA, G. L., French, E. L. \& Lind, P. E. (1961). Purification and properties of neuraminidase from $V$. cholerae. Journal of General Microbiology 24, 409-421.

AMINOFF, D. (196I). Methods for the quantitative estimation of $N$-acetyl neuraminic acid and their application to hydrolysates of sialomucoids. Biochemical Journal 81, 384-392.

Apostolov, K. \& Damjanovic, V. (1973). Selective inactivation of the infectivity of freeze dried Sendai virus by heat. Cryobiology ro, 255-259.

Burnet, F. M. \& StONE, J. D. (1947). The receptor destroying enzyme of $V$. cholerae. Australian Journal of Experimental Biology and Medical Science 25, 227-233.

ColleE, J. G. (1965). A myxovirus receptor inactivating agent occurring in cultures of Clostridium welchii. Journal of Pathology and Bacteriology 90, I-I I.

Constantopoulos, A. (1973). Distribution of sialic acid on human erythrocyte membranes. Cytobios 7, 97-102.

DrZeNIEk, R. (1973). Substrate specificity of neuraminidases. Histochemical Journal 5, 27I-290.

FIDGEN, K. J. (1973). An improved automated method for the estimation of sialic acid released in the neuraminidase assay. Analytical Biochemistry 54, 379-385.

Fraser, A. \& SMITH, J. K. (1975). Preparation of a glycoprotein fraction from pooled human plasma and its evaluation as a substrate for the assay of $C l$. welchii (C.perfringens) neuraminidase. Journal of Medical Microbiology 8 (in the Press).

GotTsChalk, A. (1957). Neuraminidase: the specific enzyme of influenza virus and Vibrio cholerae. Biochimica et biophysica acta 23, 645-646.

Heimer, R. \& MeYer, K. (1956). Studies on sialic acid of submaxillary mucoid. Proceedings of the National Academy of Sciences of the United States of America 42, 728-734.

HiRst, G. K. (194I). The agglutination of red cells by allantoic fluid of chick embryos infected with influenza virus. Science, New York 94, 22-23.

JeAnloz, R. W. (1966). $\alpha_{1}$ Acid glycoproteins. In Glycoproteins, pp. 362-394. Edited by A. Gottschalk. Amsterdam: Elsevier.

MCClelland, L. \& HARE, R. (194I). The adsorption of influenza virus by red cells and a new method for measuring antibodies to influenza virus. Canadian Journal of Public Health 32, 530-538.

MCQUIDDY, P. \& LILIEN, J. E. (1973). The binding of exogenously added neuraminidase to cells and tissues in culture. Biochimica et biophysica acta 291, 774-779.

SCHNEIR, M. L. \& RAfelson, M. E. (1966). Isolation and characterisation of two structural isomers of $N$-acetyl neuraminyllactose from bovine colostrum. Biochimica et biophysica acta 130, I-I I.

WARREN, L. (1959). The thiobarbituric acid assay of sialic acids. Journal of Biological Chemistry 234, 197I1975.

Zakstelskaya, L. YA., Molibog, E. V., Yakhno, M. A., Evstigneeva, N. A., Isachenko, V. A., Privalova, I. M. \& KHORLIN, A. YA. (1972). Use of synthetic inhibitors of neuraminidase and haemagglutinin for the study of the functional role of active subunits of membranes of myxo- and paramyxoviruses. Voprosy virusologii 72, 223-228. 